\title{
CHICAGO POLITICS-PRESENT AND FUTURE
}

\author{
BY VICTOR S. YARROS \\ Hull House, Chicago
}

Chicago is maling political history these days. Wherein lies the strength of the machine and the weakness of the opposition? Read the

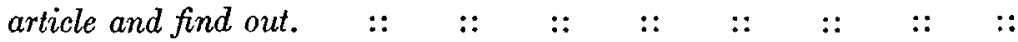

A FEw short months ago the surrender of Chicago's city council and electorate to the Thompson-Iundin machine seemed complete. Councilgovernment had ceased to exist. Outside opposition to the machine had been reduced to impotence. Apparently neither the conservative business elements which hated the machine for its waste and demagoguery, nor the sincere and progressive groups which hated it for its dishonesty, hypocrisy and greed, was able to make much headway against it. The popularity of the mayor, the nominal head of the machine, was extraordinary. It was privately said by experienced observers that Thompson could not possibly be beaten in the primaries of his own party, and that if he should care to run for a third term in 1923 he would have every reason to expect an easy victory. A competent local student of civic affairs wrote at that time in a scientific review that "anything Mayor Thompson really wants, he is extremely likely to get."

\section{THE MACHINE'S RECENT REVERSE}

But since June 6 the Chicago political and civic situation has changed considerably. The mayor and his machine have been defeated twice, and defeated rather badly. Many are confidently saying, "It's the beginning of the end of Thompsonism." This opinion is rather superficial, yet it is significant. The machine is no longer all-powerful. The popularity of its head is on the wane. In the city council new accents are heard-accents of independence and fresh courage. There is a perceptible tendency to revive council-government, as contemplated by the law, and form a non-partisan anti-machine bloc.

What has happened and what has brought about the somewhat improved situation? On June 6 , the voters of Chicago elected a coalition or nonpartisan judicial ticket and defeated the entire Thompson slate, which called itself Republican. That election amounted to a little civic revolt. The Thompson machine had defied public sentiment, had refused nominations to able and competent sitting judges whom it had found a trifle too independent and too straightforward to suit its purposes, and had nominated a factional ticket that was composed mostly of machine cogs, tools, apprentices and nonentities, a ticket so absurd as to cause the community, and especially the local bar associations and civic bodies, to gasp and stare in amazement. Its impudence was in truth colossal. The issue raised by the machine was so plain that misrepresen- 
tation, falsehood and cant-its stocks in trade - made no impression. "Save the courts" became the slogan of the anti-machine Republicans, of the Democrats and the independents.

Election day, despite fraud and trickery by agents of the machine, registered a verdict that stunned it. It had overreached itself. It had attempted to annex the judiciary and had been repulsed. Its few strong candidates shared the fate of their obscure and preposterous associates on the egregious ticket.

\section{THE LEGISLATURE BALKS}

The state legislature was in session just then, and engaged in studying several bills sponsored and wanted by the Thompson-Lundin machine, particularly the so-called Thompson People's Ownership Five-Cent Fare Traction bill. The result of the Chicago judicial contest and election made itself felt instantly at the state capitol. The machine's pet bills were re-examined and discussed with some candor and intelligence. The "downstate" members, hostile in principle to municipal ownership, and not greatly enamored either of the referendum or of home rule, first emasculated the traction bill and then killed it. And they did this in spite of the governor's pleas and protests in behalf of the measure, and in spite of patronage deals and bargains so effectively used by spoilsmen.

However, the fight is by no means over. The machine has not capitulated or disarmed. It has lost two battles, but not the campaign. It is necessary to take stock and soberly consider the relative positions of the machine and its foes. What are the present chances of the machine? What armaments and ammunition has it at its disposal? Can it recover its popularity because of the questions it is exploiting and the alluring promises it has made and continues to make?

\section{MACHINE'S PLATFORM HAS POPULAR APPEAL}

There is little difference of opinion among upright and forward-looking Chicagoans as to the main sources of the machine's prestige and strength during the last three years. The cohesive power of spoils and plunder has counted for something, but not for much. Mayor Thompson and his satellites, as well as the invisible directors of the city hall machine, have espoused and fought for these three important, "simple," and popular reforms:

1. Municipal ownership and operation, at the earliest opportunity, of Chicago's street car lines.

2. Fair and reasonable rates or charges for the services performed by those public utilities that cannot be "municipalized" in the near future, if at all, owing to perpetual franchises, financial difficulties, or other obstacles.

3. Strict enforcement, against "rich" tax-dodgers, of the revenue and tax laws of Illinois, with such revision of the statutes as shall effectually punish, preferably by imprisonment in the county jail, those who refuse or fail to fle accurate and complete tax schedules.

It is wonderfully easy for the more adroit demagogues of the machine to represent every one of its detractors and foes as a tool of the crooked public utility corporation and an apologist for wealthy and unregenerate tax-dodgers. What, it is asked with an air of innocence, is there in the Thompson platform to which any decent citizen can rationally take exception, and how can there be any honest opposition to that "simple" platform? 
NO CLEAR-CU'T OPPOSITION

The unfortunate feature of the Chicago situation is the lack of a clear, definite alignment in respect of the issues raised by the mayor and his more astute supporters.

On the question of municipalization of street railroads, for example, opinions diverge widely among the opponents of the machine. Some of them are, and have been for years, earnest advocates of public ownership of public utilities. Others believe in some form of "trustee management" and "service at cost." Still others believe in a modified "Plumb plan" applied to local utilities. Finally, the generality of business and professional men adhere to "controlled private ownership and operation." The Chicago electorate has voted for municipal acquisition and operation of the street car system and will vote again to the same effect at the first opportunity. If Thompson really favors public ownership and intends to fight for it, and not merely to manufacture political ammunition and shift responsibility for secretly desired failure on the courts, or the state legislature, or both, it is morally certain that he will win; at any rate, so far as the principle is concerned. Whether his particular traction scheme is sound and can befinanced, is another question, of course, that need not be discussed here.

With reference to the rates and charges of the utility companies, no theoretical issue is presented. Who does not favor fair and reasonable rates? The question in a particular case is whether given, or proposed, rates are reasonable. How are questions of that kind to be determined? Mayor Thompson professes to believe in "home rule"- that is, in local instead of state regulation and control of utilities. But what sort of regulation would the
Thompson machine, or any machine fashioned after its image, actually provide? Would it be scientific, or "political"? Would rates and charges be fixed in the light of honest investigations, or would they be fixed arbitrarily, to carry elections, only to strike snags in the courts? Would machine regulation give the public reasonable rates, or would it give the public costly lawsuits, injunctions, receiverships?

Finally, as regards tax-dodging. The Thompson discovery of tax-dodging is Pickwickian. Illinois adheres to the antiquated and unenforceable general property tax. Intangible personalty, naturally, escapes taxation wherever successful evasion is possible. Enlightened men have for years, or even decades, advocated constitutional amendments permitting proper classification of property for taxation, varying rates, wise exemptions and even complete modern substitutes-like the income tax-for the general property tax. Thompson and his followers either do not understand the tax problem, or do not care to deal fairly with it. Their remedy for tax-dodging is "teeth in the taxation and assessment laws," or "sending rich tax-dodgers to jail." This talk is absurd and puerile. No one fit to have an opinion on the subject takes it seriously. But-it serves the machine's political purposes. Denunciations of rich tax-dodgers sound well. You can inflame miscellaneous audiences by them, especially if you are very careful to suppress the notorious fact that tax-dodging is not a monopoly of the rich. In Illinois the average "poor" person also dodges taxes on intangible personalty. Savings banks depositors are not rich, as a rule, yet they fail to schedule their deposits. If they were to schedule such deposits, the whole return on them (3 per cent) would be taken by the state in taxes. This is confiscation, not taxa- 
tion, and no one will submit to confiscation. Thompson prefers appeals to prejudice and suspicion to rational discussion of the real revenue problem of Illinois, for intelligent, high-minded discussion of taxation does not tend to strengthen spoils machines or enhance the popularity of ambitious bosses. However, he will get nowhere in his tax crusade.

Not so with municipal ownership of the surface street railroads or with home rule in public utility regulation.

If he continues to fight for these things, no amount of merely reactionary and conservative opposition will defeat him. It behooves the genuinely progressive forces of Chicago to propose and push sound, constructive alternatives to his policies. If Chicago is not allowed to get municipal ownership of street railroads, or home rule in utilities regulation, in the "right way," she will get these desiderata in the wrong way-that is, in a way that spells waste, spoils, profligate finance, increased taxation. Tens of thousands of Chicago voters want progressive legislation, but cannot distinguish the real from the spurious article. These will indorse the Thompson plans, crude and dangerous as they may be, in the belief that there is no meritorious alternative to them.

\section{REFORMERS MUST TOLERATE EACH OTHER}

Yet there is a way to beat and destroy the Thompson machine. That way requires a little civic courage and a little intellectual honesty and foresight. It requires some sacrifice of pride and egotism.

In the first place, the heterogeneous opposition to the machine must agree to differ tolerantly on certain contentious and burning questions-such as municipal ownership, the systematic use of the referendum, and the like. In the second place, the conservative elements of the opposition must face the fact that a purely negative and obstructive policy with regard to local transportation will not answer the requirements of the situation. A sound, constructive alternative to municipalization of the traction lines will have to be worked out and proposed to the public. In the third place, effective steps must be taken to unite the anti-machine forces on a good-government platform of solid and substantial proportions.

There are such questions as simple honesty in administration, earnest regard for the interest of taxpayers, strict application of the merit principle, fit appointments to office, impartial enforcement of law. There are such questions as child welfare, police integrity, efficient administration of institutions ministering to the needs of the poor and the sick, rigorous and fearless inspection of industries and establishments that require such inspection, suppression of commercialized vice.

In short, there is the general issue of good government and efficient and economical administration. Thompsonism is subversive of good government in a hundred different ways; and the friends of good government, if they are in earnest, should be able to make common cause and successfully appeal to the public on the strength of it.

But the issue of good government must be dramatized, translated into concrete, moving human terms. Too often the phrase "good government" conveys no significant meaning to organized labor, or to the generality of the citizenry. To some it means glorified bookkeeping, or the saving of trivial sums by honest but unimaginative and unprogressive officials who neither know how, nor care to, save enormous 
sums to the public-sums appropriated by grafters and extortionists of the more respectable sort.

\section{A PROGRESSIVE PROGRAM}

Chicago has had for some time a fairly attractive and elaborate reform program, but only a few civic organizations have appreciated its significance or patiently worked for it in city and state. This program comprises: nonpartisan nomination and election of the mayor; shortening of the ballot; the adoption of the Australian ballot in its integrity; the establishment of an efficiency division in the civil service system; scientific budget making; home rule in various directions, including public utilities regulation; thoroughgoing revision of the revenue laws of the state; modernization of the tax system; simplification and rationalization of judicial procedure and practice.

An excellent program, assuredly, as far as it goes. The intelligent voters of Chicago would certainly favor it were it properly presented to them. They have, despite machine opposition, voted for several desirable changes in the last few years. They voted for non-partisan nomination and election of aldermen. They voted for a smaller and more responsible city council. They voted for city planning and for costly improvements designed to make
Chicago more attractive and healthy. There is no reason to think that the Chicago electorate is either reactionary or stupid. Issues have been confused, and coursel has been darkened. Civic reformers have been divided against themselves and have lacked courage and initiative. The spoils machine has known how to profit by the weakness and disunion of its opponents. It has known how to capitalize just discontent besides exploiting every prejudice and suspicion.

The outlook for genuine reform is not bright, but to take a sober view of the situation, and to understand the factors and circumstances that conspired to bring it about, is half to solve the difficult problem that faces Chicago and to pave the way for unity and cooperation on democratic lines, and for effective opposition to the spoils machine, a machine that has stolen the livery of municipal progress and blocked advance for a time while professing to stand for all that makes for civic righteousness. If the progressive forces of Chicago can command the wisdom and the good will which the situation demands, they have the opportunity, not only to regain control, but to force the spoils machine itself to serve the cause of the people while it lasts-to "deliver" something after all the extravagant and glowing promises it has made. 